\title{
Teachers-Students' Interaction in Early Childhood Inclusion Program
}

\author{
Lili Novitayanti ${ }^{*}$, Luh Ayu Tirtayani ${ }^{2}$ \\ 1,2 Universitas Pendidikan Ganesha
}

\section{A R T I C L E I N F O \\ Article history: Received 15 February 2019 \\ Received in revised form 29 March 2019 \\ Accepted 18 April 2019 \\ Available online 25 May 2019}

Keywords: program evaluation, social interaction, teacherstudent relations, early childhood inclusion, special education

\begin{abstract}
A B S T R A C T
UNESCO has defined inclusive education as a chance for children with disabilities to learn in the same class with their non-disable peers. It becomes the most equitable chance for those school age students with disabilities to get their right. The implementation of early childhood inclusion programs in Bali is relatively new. Thus, an analysis on its implementation is needed in order to know in extend the program is effective. This study aims to describe the effectiveness of the teachers-students social interaction in early childhood inclusion program. It is an evaluative research by focusing on the learning process, including aspects of plan, implementation, and assessment. There are 119 respondents, who are headmasters and teachers of Kindergarten, involved in this study. Data are collected through questionnaire that have been tested for being validated. The result shows that social interaction of teachers and students are: (1) positive from the aspect of planning with $\mathrm{F}+=53.781 \%$ and $\mathrm{F}-=$ $46.218 \%$, (2) not effective in the aspect of implementation with $\mathrm{F}+=47.058 \%$ and $\mathrm{F}-=52.941 \%$, and $(3)$ not effective social in the aspect of evaluation with $\mathrm{F}$ $+=42.857 \%$ and $\mathrm{F}-=57.142 \%$. It can be concluded that the social interaction of teachers and students in inclusion early childhood education program in is less effective (+- -). The teacher-students' social interaction as pivotal aspect of learning process, especially for special need students, needs to improve.
\end{abstract}




\section{Introduction}

Education is one of the basic human rights which are guaranteed and protected. It is contained in the 1945 Constitution article 31, paragraph 1 that every citizen has an equal opportunity to acquire education. Responding to their basic right of education, comes the movement "Education For All" by UNESCO (Anik, 2017). Education for all is interpreted to require that all prospective students who have abnormalities, intelligence and even a special gift for participating in learning activities in equal opportunities. Departing from the government to provide education for Special Children implemented in the form of Special Schools and Special Services. Implementation of the implementation of special education and special services currently has three forms, a form of Segregation, Integration, and Inclusion.

Inclusion is an approach to create an environment that is increasingly open to invite and involve various groups who have different backgrounds, characteristics, abilities, status, condition, ethnic, cultural and other (Achyar, 2018). It is a complex process in which it will take time and commitment to develop a clear understanding of inclusion and to implement it in reality (Cologon, 2013). Through inclusive education, the quality of education for all can be more than just a dream (Jordan, glenn, \& McGie-Richmond, 2010). By implementing good inclusive education, students with special needs can be enganged more (Fox, Farell \& Davis, 2004; Jordan, et al, 2010) which contributes to the development of their academic achievement (Cologon, 2013; deGraaf, vanHove, \& Haveman, 2013; Giangreco, 2009) even they can achieve better than those who study in non-inclusive class (Dessemontent \& Bless, 2013; Farell et al, 2007; Odom, Buyssee \& Soukakou, 2011).

Inclusive program does not only give chance for those special needs children academically, it also creates opportunity for them to enrich their communication and language skill (Fisher \& Shorgren, 2012; Hart \& whalon, 2011; Kliewer, 2008; Stahmer, et al, 2011), social competence (Buyssee \& Soukakou, 2011; Finke, et al, 2009; Hanline \& Correa-Torress, 2012; Jordan, et al, 2009), and positive behavior (Diamond \& Huang, 2005; Hollingsworth, Boone, \& Crais, 2009; Mogharreban \& Bruns, 2009). Physically, children with special needs also grow well in inclusive school setting (Theodora \& Nind, 2010; Qi \& Ha, 2012).

Schools, which implement inclusive education with various diversity characteristics of learners and environmental conditions, need to make adjustments to improve the quality of education. This condition requires serious effort so that children with special needs get good access to education. The success of an educational program is inseparable from the components of the program itself. One crucial factor is the teacher factor in guiding the students in learning activities. In inclusion education, the competency of teachers, including individual, social, professional, and pedagogical, are really a must. Delpie (2016:18) revealed that the classroom teacher plays an important role in the validity as a member of an integrated team (interdisciplinary team) that gives a decision against the student participants in a process of the placement of learners. Integrated Team (interdisciplinary team) on inclusive education should ideally involve professional experts for the planning of individual learning programs. Experts who may be involved include Psychologists, Counselors, Health Specialist / Doctors, therapists, and social workers, as well as outstanding educators, teachers, parents, and principals.

Besides, teachers attitude on the program really impact the implementation of inclusive practice in the classroom (Carlson, et al, 2012; Curcic, 2009; Huang \& Diamond, 2009). Building positive attitude of the teachers toward the program can be done by giving education and experience as well as supports to the teacher (Avramidis \& Norwich, 2002; Cologon, 2012; and Jordan, et al, 2010). Cologon (2012) mentioned that those teachers who received education about inclusion have more positive attitude toward the program. However, Guralnick \& Bruder (2016) stated that in order to meet all the requirements of children in classroom setting, teacher must be competent in pedagogy, includes philosophy, knowledge, and skills to implement a developmentally appropriate curriculum with adaptation and modification.

The important role of the teacher in a learning activity will not run well or become ineffective if the teacher does not have good social interaction ability criteria. Criteria for good social interaction according to (Soekanto, 2015: 58) are when individuals can make social contacts well, both primary and secondary contacts, and this is characterized by the ability of individuals to have conversations with others, understand each other, and can cooperate with other people. Also, individuals need to have the ability to communicate with others, which is characterized by a sense of openness, empathy, providing support, feeling positive towards others, and having similarities or being called equality with others. Ginintasasi 
(2012) explains that social interaction is a relationship between individuals one with another individual or group, which individual behavior can affect other individuals or groups, and vice versa.

The implementation of learning activities in the inclusion setting applies general principles as well as implementing specific principles by the abnormalities of students because in the inclusion setting there are students who have diverse characteristics. The stages of the inclusive class learning activities program are planning, implementing and assessment the learning activities program. Suhendri (2018) found several obstacles found in the implementation of inclusive education such as the lack of facilities to support the inclusive education system, the limited knowledge, and skills possessed by inclusive school teachers. The above problems are reinforced by the findings of problems in the field when researchers observe.

Based on observations, one of the problems complained by educators is the lack of readiness of teachers to carry out inclusion programs so that teachers have not dared to accept ABK students in more than one number in each class. As well as facilities and infrastructures that are lacking also become obstacles in the acceptance of students. Teachers' skills are still lacking in making learning design so that the daily lesson plan used was equated with design activities in general. Iswardhany (2016) in his study mentioned that one of the problems that make social interaction of teachers and students are less effective because of the lack of ability of teachers to manage the interaction of students in learning activities. With no good social interaction between teachers and students, students will feel the lack of attention from teachers and a lack of motivation to learn given by the teacher to the students.

Based on the problems found in the field, it is necessary to evaluate the social interactions of teachers and students in early childhood education program inclusion that is important to do to determine the extent to which the effectiveness of the implementation of Inclusion early childhood education standards are implemented in their implementation. In evaluations there is a process of collecting and presenting information about the object of evaluation, giving an evaluation of the evaluation standards and the results used to make decisions about the object of evaluation. The evaluation model used in this study is the CIPP Evaluation Model. The CIPP evaluation model was developed by Stufflebeam in 1967, which is an abbreviation of the initial four letters, namely Context, Input, Process, and Product (Ananda, 2017).

The CIPP model was chosen by researchers based on the workings of evaluating the CIPP model which looked at evaluation as a system, and the accuracy of the use of evaluation models for processing programs such as evaluations conducted by researchers on the interaction of teachers and students in PAUD Inclusion. In this study only using measurements through process variables because it only discusses how far the activities carried out in a program have been carried out by the plan seen from the process of social interaction of teachers and students in learning activities seen from aspects of learning planning, implementation of learning, and assessment.

Evaluation of the process is an evaluation of management, leadership, and especially the process of teaching and learning activities. In education, the process is changing events that have not been educated learners to become educated learners. The quality of the teaching and learning process is very dependent on the quality of the interaction between the teacher and students. The behavior of the teacher in the classroom, such as the clarity of the teaching, the use of variety of teaching methods, the variation in the use of media, the seriousness of the teachers teach, how teachers are doing apperception, classroom management, use of time, discipline, empathy towards the learner, interpersonal relationships, expectations, teaching innovations, and the use of the principles of effective learning.

The research objective to be achieved from the evaluation of social interaction of teachers and learners in learning activities in early childhood Inclusion Denpasar are as follows: (1) to determine the effectiveness of the social interaction of teachers and students in the program of early childhood inclusion in Denpasar from the aspects of planning, (2) to find out the effectiveness of the social interaction of teachers and students in the program of early childhood inclusion in Denpasar from the aspects of implementation, and (3) to determine the effectiveness of the social interaction of teachers and students in the program of early childhood inclusion in Denpasar from the aspects of assessment.

\section{Methods}

Evaluation of the social interactions of teachers and students was carried out in all Inclusion PAUD in Denpasar. This research is a type of evaluative research with a focus on process variables which include aspects of planning, implementation, and assessment. The population in this study is PAUD Inclusion in Denpasar which consists of 4 sub-districts with 19 schools that have been recommended by the Office of Education, Youth and Sports of Denpasar. After initial observations to ensure the suitability 
of the schools recommended with the characteristics of the research criteria, 6 schools did not comply with the research characteristic criteria set by the researchers. Based on these reasons, the population obtained in the study of early childhood inclusion in Denpasar as many as 13 schools with a total number of respondents was 119 educators. In this study, Purposive Sampling was used because researchers wanted to research all Inclusion PAUD in Denpasar.

In this case focused on the subject of his research head of kindergarten and class teachers (KB, Group A, Group B). The reason for choosing the head of the kindergarten as a research subject for kindergarten head acts as responsible in the school that he led and the average head TK also doubles as a teacher. While the teachers were chosen as the focus of this study to look at the process of teacher interaction with students directly involved in the process of learning activities ranging from lesson planning, implementation of learning, and assessment.

Data collection for this study was conducted through a questionnaire or questionnaire method. The form of the questionnaire used was the Likert Scale in the form of a Checklist. The instrument grid in this study is a modification of the instrument used in previous studies, namely research from Tirtayani, Sujana, \& Ganing (2018). The instrument grid in this study is:

Table 1. Instrument Grid

\begin{tabular}{|c|c|c|}
\hline Variable & Aspect & Indicator \\
\hline \multirow{5}{*}{ Process } & Planning & $\begin{array}{l}\text { Indicators in the process of social interaction between teachers and } \\
\text { students are seen from the planning of learning activities which include: } \\
\text { 1. Clarity of the formulation of learning objectives } \\
\text { 2. Planning learning design } \\
\text { 3. Planning class management } \\
\text { 4. Planning to organize and using materials/sources/ learning media } \\
\text { 5. Plan for a strategic approach to teaching and learning activities } \\
\text { 6. Planning procedures for teaching and learning activities }\end{array}$ \\
\hline & Implementation & $\begin{array}{l}\text { Indicators in the process of teacher and student social interaction are seen } \\
\text { from the implementation of learning activities which include: } \\
\text { 1. Implement apperception }\end{array}$ \\
\hline & & 2. Presenting material \\
\hline & & $\begin{array}{l}\text { 3. Implement methods, learning resources/media, and training materials } \\
\text { that are by the initial abilities and characteristics of students, and by } \\
\text { the learning objectives } \\
\text { 4. Encourage students to be actively involved } \\
\text { 5. Building interpersonal relationships }\end{array}$ \\
\hline & Assessment & $\begin{array}{l}\text { Indicators in the process of teacher and student social interaction seen } \\
\text { from the assessment include: } \\
\text { 1. Type of Assessment } \\
\text { 2. Time of Assessment } \\
\text { 3. Assessment Instrument }\end{array}$ \\
\hline
\end{tabular}

After the instrument is made then validity is tested so that valid data can be obtained. The instrument in this study uses two types of validity tests, namely construct validity and validity of items or items. The results of the calculation of construct validity, the research instrument on the planning aspect obtained a result of 0.931 , in the implementation aspect obtained a result of 0.962 , and in the assessment, aspect obtained a result of 1.00 . If the calculation results of the three are added to the coefficient moves from the range of 0.00 to 1.00 then the validity of the results of the three components of the aspects that are in the range of 0.80 to 1.00 , which means the items in the statement of this instrument is very high.

The results of the calculation on the item validity test using the Try Out test showed the following results: in the planning aspect, item number 13 was stated to be Drop or Invalid because the calculation

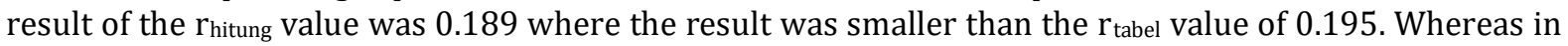
the implementation aspect item number 12 is stated to be Drop because the calculation result of $\mathrm{r}_{\text {hitung }}$ count is 0.152 where the result is smaller than the $r_{\text {tabel }}$ value which is 0.195 . In the assessment aspect, there are no statements that are dropped or declared invalid because the results of the rhitung of all items are greater than the results of the $r_{\text {tabel. }}$

After doing the validity test, it continued with the calculation of reliability using the Cronbach Alpha formula. Reliability testing is done on the items that have been validated and declared valid. Obtained 
reliability calculation results on the planning aspect questionnaire of 0.766 which is included in the category of a high degree of reliability. On the results of the reliability calculation on the implementation aspect questionnaire of 0.834 which is included in the category of a very high degree of reliability. On the results of the reliability calculation on the assessment aspect questionnaire of 1.04 which is included in the category of a very high degree of reliability.

The data analysis technique in this study is by finding the final result in the form of a T-score. To retrieve the final result is calculated by summing the results of the T-score positive (+) and negative (-). If the number of positive scores is more than the negative score means the result is positive $(\Sigma$ skor $(+)>$ $\Sigma$ skor $(-)=+)$, vice versa if the number of positive scores is smaller than the negative score then the result is negative $(\Sigma$ skor $(+)<\Sigma$ skor $(-)=-$ ). Then an analysis of the process variables that have been obtained through Glickman quadrant analysis is divided into four quadrants.

To determine the level of effectiveness of the social interactions of teachers and students in the learning activities in PAUD Inclusion, an analysis of process variables through Glickman quadrant analysis was divided into four quadrants. If the results of data analysis show all the results are positive $(+)$ in quadrant I, which means "Very Effective", on the contrary, if the results of data analysis show all the results are negative (-) in quadrant IV which means "Very Less Effective". If the results of data analysis, two variables show positive results, then they are in quadrant II, which means "Effective enough". While the variable indicates a negative result then is in quadrant III, which means "Less Effective".

\section{Research and Discussion}

\section{a. Effectiveness of Social Interaction of Teachers and Students on Aspects of Planning}

The effectiveness of social interaction of teachers and students in the early childhood inclusion program in Denpasar seen from the aspect of planning that consists of several indicators, namely, the clarity of the formulation of learning objectives, plan learning design, planning classroom management, planning organization and the use of materials/resources/media, planning strategies for approaching teaching and learning activities, and planning procedures for teaching and learning activities. It is in line as what Majid (2005:17) mentioned that the context of a learning plan can be defined as the process of preparing a subject matter, use of media, the use of the approach or method of learning, and assessment in a location that will be implemented on a time-limited period to achieve predetermined objectives. The planning needs to consider the needs and characters of students in order to help the students achieving the goals. Especially in inclusive education, it is not the children who 'fit' with the setting, but more about changing the setting to include the child in inclusion (Armstrong, Armstrong, \& Pandagou, 2011; Cologon, 2013; Lalvani, 2013; Rietveld, 2010).

Based on the results of this research in the aspect of planning, the indicators have been set clearly. Besides, the learning goals are already formulated precisely. They are designed based on the requirement of the syllabus and consider the different ability and needs of the students in inclusive classes. Teachers need to consider many aspects. In order to plan a good teaching and learning process in inclusive class, Runcharoen (2014) mentioned that the teachers should cooperate in observing the social interaction of each child, so they will get the basic information to be used in planning the lesson.

In terms of designing the learning in teacher inclusion classes, many teachers mentioned that they have planned and designed the learning based on the students uniqueness with full consideration on the special needs of the special students. Unfortunately, it was also found some of the respondents who did not modify the learning design based on the needs of students with special needs. It should be remembered that one of the common principle in inclusive practice is that instruction, including media, must be individualized for each child in all setting (Frankel \& Underwood, 2012). They mentioned that it is quite difficult to do that and they need more examples and guides to be familiar in doing the need analysis. Considering the characteristics and needs of students are very crucial in planning the learning, even for inclusive program.

The indicators for classroom management plan is the next item to be responded in questionnaire distributed for headmasters and teachers. The result shows that the teachers plan classroom management according to the characteristics and needs of students in the inclusion class. Even though most of them mentioned that they consider much on the needs of the special students, there are still some teachers who still find difficulties doing it. It is in line with the result of case study conducted by Wysocki (2018) who found out that a teacher in inclusive class was very frustrated and challenged to handle students with IDEA in the beginning. But by creating a caring classroom atmosphere, it can ultimately promote students engagement and participation within the lesson (Wysocki, 2018).

Teachers have critical role to play in adapting the environment and making changes to teaching approaches and materials in order to include every child (Avramidis \& Norwich, 2002; Biklen, 2000, 
Cologon, 2013). On indicators planning to organize and using materials, sources, instructional media, teachers can already plan it according to the students needs and can pay attention to every aspect of child development as well as pay attention to the use of media and learning resources of students in the inclusion class. But in the selection of sources or media that will be used in the implementation of learning in inclusive classes, there are still some teachers who still feel difficult. Actually, lack of teachers education and supports become the reason of the failed inclusion program (Brown, et al, 2013). Teachers require support from the other stakeholders to prepare them for having experience in inclusive class (ARACY, 2013).

For the last indicator, planning strategies for learning activities, the teacher can plan strategies and methods of learning by not differentiating the social status of students in inclusive classes and designing strategies and methods in a variety of ways to create good social interactions. Pupuh Faturrahman (in Khadija, 2016) explains that there are at least five strategies that can be developed to create or build interactions with effective communication between teachers and students, one of which is Respect which is mutual respect and does not distinguish social status.

Looking at the result in planning, it can be concluded that most of the teachers have awareness and competency in planning the lesson for inclusive classroom. Even some of the still find difficulties in planning some indicators of the aspect, but it is purely because the teachers have lack of knowledge, examples, and practice. Teachers can develop their ability in inclusive program through experience and support (Avramidis \& Norwich, 2002; Cologon, 2012; and Jordan, et al, 2010).

\section{b. Effectiveness of Social Interaction of Teachers and Students on Aspects of Implementation}

For the next aspect, which is aspect of implementation, several indicators are evaluated, namely, implementing apperception, presenting the materials, implementing the method, source/media learning, and training materials in accordance with the initial capabilities and characteristics of students, and in accordance with the purpose of learning, encouraging students to be actively involved, and fostering personal relationships.

Less effective results of the analysis of the implementation aspects are caused by several indicators in terms of implementation. Djamarah \& Zain (2015) explained that the implementation of learning is an activity that has educational value, educative value coloring the interactions that occur between teachers and students. Interactions due to implementation of the educational value of learning undertaken directed to achieve certain goals that have been formulated before the learning begins. In aspects of the implementation of this research, the indicator components are less effective, namely, the teachers still feel difficulties when trying to create a situation that leads to the occurrence of a pleasant learning environment for all students, especially children with special needs. Similarly, in presenting learning materials in the inclusive classroom, there are still some teachers who feel a little difficult to build and establish a process of social interaction with students with special needs.

Koenen (2017) in his research said that the quality of the social interaction of teachers and students was not qualified or became ineffective due to several reasons. First, the symptoms of fatigue such as emotional exhaustion and depersonalization as feeling indifferent, and indifference to the learner unconsciously. Second, less supportive teaching style as it does not involve all students in the classroom inclusion in learning activities. Third, less of classroom management because teachers are not effective in dealing with problems that occur in the classroom. Fourth, the lack of support from the surrounding.

In such cases, according to information obtained from multiple sources respondents researchers due to the lack of socialization, seminar or workshop of stakeholders on the handling of children with special needs in inclusive classes, as well as serialize regarding inclusion programs that have an impact on the lack of effective social interactions that occur. The Directorate of Special Education Development and Special Services (in the Ministry of National Education, 2019: 4) also said that other issues of implementing the inclusion program, namely the continuation of guidance from schools that provide inclusive education to pilot schools are still not working properly.

In its implementation, several schools that were visited by researchers in terms of the learning media used were still not following the needs and learning objectives in the inclusion class settings due to limitations. The result was supported by Dewi (2017) who mentioned that the unpreparedness of human resources and supporting the infrastructure of one of the issues that are still frequently encountered in the implementation of inclusive education. Implementation of the field of education tends to judge that if children with special needs are given the same educational services and concurrently with normal children then it will only interfere with the educational process and it will give impact for a normal child. This pattern of education will have an impact on both children with special needs and normal children, namely apathy, disrespect, lack of confidence, individualism, and not ready to live in the community. 


\section{c. Effectiveness of Social Interaction of Teachers and Students on Aspects Assessment}

There are some indicators related with the aspect of assessment in this research, namely, the type of assessment, time assessment, and assessment instruments. Less effective of the results of the analysis on the aspect of assessment is caused by several indicators in terms of assessment. Rosenberg (1982) (in Ambara, et al., 2014: 54) stated that an assessment or assessment is a process of gathering the information that will be used to make judgments and decisions relating to children' learning. Assessment of learning outcomes in inclusive education settings needs to be flexible, to be sustainable, authentic and comprehensive. Every teaching and learning activity must have objectives that need to be assessed in different ways. Assessment must describe learning outcomes, which provide an overview of the success of students in developing a series of skills (psychomotor), knowledge (cognitive), and behavior (affective) during learning, topics or flexible curriculum.

In the aspect of assessment of this study, there is no difference in assessing students with special needs and regular students. In terms of diversity assessment some teachers still provide flexibility to teachers to apply arbitrarily the appropriate type of assessment and learning outcomes assessment is done by using any method (written tests, observation, through a portfolio, performance, product, assignment, and others). According to Sukinah (2017), diversity assessment is not intended to provide flexibility teachers to apply arbitrarily certain types of assessments. But on the contrary, with their diversity of these assessments, teachers are required to be professional and responsible when determining the selection of the type of assessment that will be used.

Being an inclusive teacher requires unlimited patience in handling children with special needs in their class. Children with special needs are difficult to be directed and to follow regular learning activities. This is still one of the difficulties of the teacher in terms of making an objective assessment. Their techniques in establishing a good social interaction to get a positive result at the time of evaluation. Evaluation or assessment is given to children with special needs, one of which must be able to communicate appropriately. Early childhood is still difficult to communicate or convey messages well. According to Bayu and Nyoman (2019) communicating openly like their parents is one way that is quite effective in establishing effective interactions between teachers and students. By creating a communication style that is similar to their parents at home when it is expected that children can express they are well wishes, the assessment of teachers will be easy and will be objective.

\section{Conclusions}

Based on the results of research and in-depth discussion, the conclusions obtained from this study is the evaluation of the social interaction of teachers and students in the early childhood inclusion program in Denpasar is less effective reviewed through several component aspects, including all aspects of planning, implementation, and assessment. The planning aspect gets effective results. Whereas in other aspects, the implementation aspects and assessment aspects show less effective results. As the conclusion, the social interaction of teachers-students in PAUD in Denpasar need to be improved in order to give the same opportunities for children with special needs to learn.

\section{References}

Achyar, 2018."Permasalahan Pendidikan Inklusif di Indonesia". Tersedia pada http://tkplb.kemdikbud.go.id/index.php/berita/info-diklat/permasalahan-pendidikan-inklusif-diindonesia (diakses tanggal 5 Februari 2019).

Ambara, Didith Pramunditya, dkk.2014.Asesmen Anak Usia Dini. Yogyakarta:Graha Ilmu.

Anik.2017."Mewujudkan Sekolah Inklusi Merujuk Pada Pendidikan Untuk Semua". Tersedia pada https://www.kompasiana.com/twin/5a00470dc226f97a1a0f8482/mewujudkan-sekolah-inklusimerujuk-pada-pendidikan-untuk-semua?page=all (diakses tanggal 7 Februari 2019).

Anita, S. D., Jones, P., Luckner, J., Kreimeyer, K. H., \& Reed, S. (2011). Social outcomes of students who are deaf and hard of hearing in general education classrooms. Exceptional Children, 77(4), 489-504.

Arikunto, Suharsimi dan C.S.A Jabar.2014.Evaluasi Program Pendidikan.Jakarta: Bumi Aksara.

Armstrong, D., Armstrong, A.C. \& Spandagou, I. (2011). Inclusion: By choice or by chance? International Journal of Inclusive Education, 15(1), 29-39. doi:10.1080/13603116.2010.496192

Avramidis, E. \& Norwich, B. (2002). Teachers' attitudes towards integration/inclusion: A review of the literature. European Journal of Special Needs Education, 17(2), 129-147. doi:10.1080/08856250210129056 
Bayu, Gede Wira dan Nyoman Kusmariyatni.2019."Patterns Of Care (Parenting) Children with Special Needs". Journal of Educational Research and Evaluation, Volume 3, Number 1 (hlm. 39-45). Tersedia pada https://ejournal.undiksha.ac.id/index.php/JERE/article/viewFile/17770/10636 (diakses tanggal 14 Juli 2019).

Biklen, D. (2000). Constructing inclusion: Lessons from critical, disability narratives. International Journal of Inclusive Education, 4(4), 337-353. doi:10.1080/13603110050168032

Brown, C. M., Packer, T. L., \& Passmore, A. (2013). Adequacy of the regular early education classroom environment for students with visual impairment. Journal of Special Education, 46(4), 223-232.

Carlson, L., Hemmings, B., Wurf, G., \& Reupert, A. (2012). The instructional strategies and attitudes of effective inclusive teachers. Special Education Perspectives, 21(1), 7-20.

Cologon, K. (2013). Inclusion in education: Towards equality for students with disability. Children with Disability Australia, Issues Papers. Retrieved www.cda.org.au/_literature_159457/Issues_Paper_on_Inclusion_-_PDF

Curcic, S. (2009). Inclusion in PK-12: an international perspective. International Journal of Inclusive Education, 13(5), 517-538.Delphie, Bandi.2009.Pembelajaran Anak Berkebutuhan Khusus dalam Setting Pendidikan Inklusi.Sleman: PT Intan Sejati Klaten.

deGraaf, G., van Hove, G. \& Haveman, M. (2013). More academics in regular schools? The effect of regular versus special school placement on academic skills in Dutch primary school students with Down syndrome. Journal of Intellectual Disability Research, 57(1), 21-38. doi:10.1111/j.13652788.2011.01512.x

Depdiknas.2019.Rencana Induk Pengembangan Pendidikan Inklusif Tingkat Nasional Tahun 20192024.Jakarta: Depdiknas.

Dessemontet, R.S. \& Bless, G. (2013). The impact of including children with intellectual disability in general education classrooms on the academic achievement of their low-, average-, and highachieving peers. Journal of Intellectual \& Developmental Disability, 38(1), 23-30. doi:10.3109/13668250.2012.757589

Dewi, Nurul Kusuma.2017."Manfaat Program Pendidikan Inklusi untuk AUD”.Jurnal Pendidikan Anak, Volume 6, Edisi 1 (hlm. 1-19). Tersedia pada https://journal.uny.ac.id/index.php/jpa/article/view/15657 (diakses tanggal 7 Februari 2019).

Diamond, K.E. \& Huang, H-H. (2005). Preschoolers' ideas about disabilities. Infants \& Young Children, 18(1), 37-46. Retrieved from http://journals.lww.com/iycjournal/pages/Default.aspx

Djamarah, Syaiful Bahri dan Aswan Zain.2015. Strategi Belajar Mengajar.Jakarta: Rineka Cipta.

Farrell, P., Dyson, A., Polat, F., Hutcheson, G. \& Gallannaugh, F. (2007). SEN inclusion and pupil achievement in English schools. Journal of Research in Special Education Needs, 7(3),172-178. doi:10.1111/j.1471-3802.2007.00094.x

Fisher, K.W. \& Shogren, K.A. (2011). Integrating Augmentative and Alternative Communication and peer support for students with disabilities: A social-ecological perspective. Journal of Special Education Technology, 27(2), 23-39. Retrieved from www.tamcec.org/jset/index/

Fox, S., Farrell, P. \& Davis, P. (2004). Factors associated with the effective inclusion of primary-aged pupils with Down's syndrome. British Journal of Special Education, 31(4),184-190. Retrieved from http://onlinelibrary.wiley.com/journal/10.1111/(ISSN)1467-8578Ginintasasi,

Rahayu.2012.Interaksi Sosial.Jurusan Psikologi, Universitas Pendidikan Indonesia. Tersedia pada http://file.upi.edu/Direktori/FIP/JUR._PSIKOLOGI/195009011981032-

RAHAYU_GININTASASI/INTERAKSI_SOSIAL.pdf (diakses tanggal 7 Februari 2019).

Frankel, E. \& Underwood, K. (2012). Early Intervention for Young Children, in I. Brown \& M. Percy (Eds) Developmental Disabilities in Ontario, 3rd edn. Toronto: OADD.

García-Carrión R, Molina Roldán S \& Roca Campos E. (2018). Interactive Learning Environments for the Educational Improvement of Students With Disabilities in Special Schools. Front. Psychol. 9:1744. doi: 10.3389/fpsyg.2018.01744

Giangreco, M. (2009). Opportunities for children and youth with intellectual developmental disabilities: Beyond genetics. Life Span and Disability, 12(2), 129-139. Retrieved from www.lifespan.it

Guralnick, M.J. \& Bruder, M.B. (2016). Early Childhood Inclusion in the United States Goals, Current Status, and Future Directions. Infants \& Young Children Vol. 29, No. 3, pp. 166-177. DOI: 10.1097/IYC.0000000000000071

Hanline, M. F. \& Correa-Torres S. M. (2012). Experiences of Preschoolers with Severe Disabilities in an Inclusive Early Education Setting: A Qualitative Study. Education and Training in Autism and Developmental Disabilities, 47(1), 109-121.

Hart, J.E. \& Whalon, K.J. (2011). Creating social opportunities for students with autism spectrum disorder in inclusive settings. Intervention in School \& Clinic, 46(5), 273-279. 
doi:10.1177/1053451210395382

Hollingsworth, H.L., Boone, H.A. \& Crais, E.R. (2009). Individualized inclusion plans work in early childhood classrooms. Young Exceptional Children, 13(1), 19-35. doi:10.1177/1096250609347259

Huang, H.-H., \& Diamond, K. E. (2009). Early childhood teachers' ideas about including children with disabilities in programmes designed for typically developing children. International Journal of Disability, Development and Education, 56(2), 169-182.

Iswardhany, Rieske.2016."Pengaruh Interaksi Sosial Guru dengan Siswa Terhadap Motivasi Belajar di Jurusan Teknik Gambar Bangunan SMK Negeri 1 Cilaku Cianjur". Jurnal disajikan dalam Seminar Nasional dan Pameran Produk Pendidikan Vokasi ke 1, FKIP-UNS (hlm 548-558). Tersedia pada https://jurnal.uns.ac.id/uvd/article/view/7228 (diakses tanggal 8 Februari 2019).

Jordan, A., Glenn, C. \& McGhie-Richmond, D. (2010). The Supporting Effective Teaching (SET) project: The relationship of inclusive teaching practices to teachers' beliefs about disability and ability, and about their roles as teachers. Teaching \& Teacher Education, 26(2), 259-266. doi:10.1016/j.tate.2009.03.005

Kliewer, C. (2008). Seeing all kids as readers: A new vision for literacy in the inclusive early childhood classroom. Baltimore: Paul H. Brookes Publishing Co.

Koenen, Anne-Katrien.2017."Teachers' Daily Negative Emotions in Interactions With Individual Student in Special Education". Journal of Emotional and Behavioral Disorder (hlm. 1-15). Tersedia pada https://journals.sagepub.com/doi/full/10.1177/1063426617739579 (diakses tanggal 17 Juli 2019).

Lalvani, P. (2013). Privilege, compromise, or social justice: Teachers' conceptualizations of inclusive education. Disability \& Society, 28(1), 14-27. doi:10.1080/09687599.2012.692028

Majid, Abdul.2005.Perencanaan Pembelajaran.Bandung: PT Remaja Rosda Karya

Mogharreban, C. \& Bruns, D. (2009). Moving to inclusive pre-kindergarten classrooms: Lessons from the field. Early Childhood Education Journal, 36(5), 407-414. doi:10.1007/s10643-008-0301-0

Odom, S.L., Buysse, V. \& Soukakou, E. (2011). Inclusion for young children with disabilities: A quarter century of research perspectives. Journal of Early Intervention, 33(4), 344-356. doi:10.1177/1053815111430094

Qi, J. \& Ha, A.S. (2012). Inclusion in physical education: A review of literature. International Journal of Disability, Development and Education, 59(3), 257-281. doi:10.1080/1034912X.2012.697737

Rietveld, C. (2010). Early childhood inclusion: The hidden curriculum of peer relationships, New Zealand Journal of Educational Studies, 45(1), 17-32. Retrieved from http://hdl.handle.net/10092/5223

Runcharoen, S. (2014). The development of social interaction of children with autism in inclusive classrooms. 5th World Conference on Educational Sciences - WCES. Procedia - Social and Behavioral Sciences 116 pp. $4108-4113$

Soekanto, Soerjono. 2014.Sosiologi Suatu Pengantar.Jakarta: Rajawali Pers.

Stahmer, A.C., Akshoomoff, N. \& Cunningham, A.B. (2011). Inclusion for toddlers with autism spectrum disorders. The International Journal of Research \& Practice, 15(5), 625-641. doi:10.1177/1362361310392253

Suhendri. 2018." Pendidikan Inklusif". Tersedia pada http://tkplb.kemdikbud.go.id/index.php/konten/martikel/martikel-inklusi/215-pendidikaninklusif (diakses tanggal 7 Februari 2019).

Sukinah. 2017. Sistem Penilaian Hasil belajar Anak Berkebutuhan Khusus dalam Implementasi Pendidikan Setting Inklusi. Universitas Negeri Yogyakarta. Tersedia pada http://staff.uny.ac.id/sites/default/files/SISTEM\%20penilaian\%20sistem\%20inklusif\%201.pdf (diakses tanggal 10 Februari 2019).

Theodorou, F. \& Nind, M. (2010). Inclusion in play: A case study of a child with autism in an inclusive nursery. Journal of Research in Special Educational Needs, 10(2), 99-106. doi:10.1111/j.14713802.2010.01152.x

Tirtayani, L.A, I.W Sujana, N. Ganing. 2018. "Analisis Kesiapan Pendidik terhadap Penyelenggaraan Program PAUD Inklusi di Bali". Laporan Penelitian. Denpasar: LPPM Undiksha.

Undang - Undang Dasar Negara Republik Indonesia Tahun 1945 pasal 31 ayat 1.

Uno, Hamzah B.Perencanaan Pembelajaran.2006.Jakarta: Bumi Aksara.

Wysocki, C.D. (2018). Obstacles to Inclusion: One Early Childhood Inclusive Teacher's Perspective. IntechOpen. DOI: $h$ ttp://dx.doi.org/10.5772/intechopen.80982 